\title{
Neutralizing potential of Rauvolfia serpentina root extract against Naja naja venom
}

\author{
Thulasi Sivaraman $^{1 *}$, Nadooparambil Sasi Sreedevi', Subramani Meenachisundharam², \\ Ramachandran Vadivelan ${ }^{\circledR 3}$
}

\begin{abstract}
${ }^{1}$ Department of Microbiology, Nehru Arts and Science College, Coimbatore, Tamil Nadu, India, ${ }^{2}$ Department of Microbiology, Nehru Arts and Science College, Coimbatore, Tamil Nadu, India, ${ }^{3}$ Department of Pharmacology, JSS College of Pharmacy, Ooty, Tamil Nadu, India
\end{abstract}

\begin{abstract}
Snake bites are a serious health hazard occurs throughout the world especially in tropical countries like India. Anti-Snake Venom Serum is the only remedy available to treat snake bite victims successfully till date. Infusion of ASV may lead to adverse reactions ranging from severe itching of the skin, hives to potentially serious allergic reactions. Considering all above difficulties research workers all over the world is constantly in search of a cheap and readily available easy formulate remedy for treating snake bite victims. In present study aqueous extract of Rauvolfia serpentina root was checked for the antidote properties against Naja naja venom by in vitro and in vivo methods. Various in vitro neutralization tests like Acetyl cholinesterase, Protease and ATPase activity of Naja naja venom were carried out and the root extract was neutralized all the toxic effects induced by the venom. The in vivo assessment of venom lethality $\left(\mathrm{LD}_{50}\right)$ of Naja naja venom was found to be $0.301 \mu \mathrm{g}$. The aqueous root extract was effectively neutralized the venom lethality and effective dose $\left(\mathrm{ED}_{50}\right)$ was found to be $12.88 \mathrm{mg} / 3 \mathrm{LD}_{50}$ of Naja naja venom. LC-MS analysis from root extract of Rauvolfia serpentina was done for confirmation of the bioactive compounds.
\end{abstract}

Keywords: Snake bite. Naja naja. Rauvolfia serpentina. Antivenom compounds.

\section{INTRODUCTION}

Snakebite envenoming is a neglected tropical disease which requires immediate consideration. Every year 2.5 million people are bitten by snakes with 85,000 deaths (Gutierrez et al., 2010). Agriculturists and their families living in rural areas of the country are the most affected community, thus snakebite is represented as 'disease of poverty' (Harrison et al., 2009). A total number of snake species identified is about 2,000 to date and nearly 300 species of them are venomous snakes, which prevail over all parts of the world except Antarctica (Mohapatra et al., 2011). The four major species of venomous snakes ubiquitous in India known as "Big four" are considered responsible for life-threatening envenomation around the country (Mukherjee, 2012). The most common enzymes in snake venoms are phospholipase $\mathrm{A}_{2} \mathrm{~s}\left(\mathrm{PLA}_{2} \mathrm{~s}\right)$, serine proteinases, metalloproteinase,

\footnotetext{
*Correspondence: T. Sivaraman. Department of Microbiology, Nehru Arts and Science College. Tamil Nadu, India. Phone: +919656339212. E-mail: thulasiyedhul@gmail.com
}

acetyl cholinesterase (AChEs), 1-amino acid oxidases, nucleotides (5'-nucleotidase, ATPase, phosphodiesterases and DNase) and hyaluronidase. Snake venoms are the most abundant source of all these enzymes (Kang et al., 2011). The venom of Naja naja is neurotoxic, they affect the victim's central nervous system and cause heart failure. The venoms are rich in post synaptic neurotoxins called alpha-bungarotoxin and cobratoxin. Venom binds particularly to Acetylcholine receptors, prevents the interaction between Acetylcholine and receptors on post synaptic membrane result in neuromuscular blockade (Bawaskar, 2014). Antiserum is the only therapeutic agent available throughout the world. The antiserum development is a costly, time-consuming process requiring ideal storage conditions. Absolute specificity is an issue in management with antiserum. Snake venom antiserum does not provide adequate safety against venom induced local pain, local bleeding swelling and difficulty including wound necrosis, hemorrhage, necrosis and nephrotoxicity (Sarkhel et al., 2011). Over the years, many attempts have been made for the advance of snake venom antagonists 
particularly from plants sources since there are limitations on the expansion of anti-sera (Khan et al., 2014). In folk medicine, many botanical species are employed for the treatment of snakebites in communities that lack rapid access to serum therapy especially in developing countries. Herbal components play an important role in management and controlling of venomous snake bite (Vijaya et al., 2013).

Rauvolfia serpentina (L.) Benth. ex Kurz. (Ophioxylon serpentinum L.) is an evergreen, perennial shrub with maximum height up to $60 \mathrm{~cm}$ (Deshmukh, Dhanashree, Patil et al., 2012). The plant belongs to the family Apocynaceae and occurs to habitats of tropical and subtropical regions. The plant is commonly known as Sarpagandha, Chandrabagha, Snake root plant, Chotachand, Chandrika and Harkaya etc (Mallick, Jenna, Samal, 2012). The roots of Rauvolfia serpentina are used in Ayurvedic medicines as a treatment for curing hypertension, insomnia, mental anxiety, gastrointestinal disorders, anticipation epilepsy, trauma, anxiety, stimulation, schizophrenia, sedative insomnia and psychosis (Rathore et al., 2012). It is used as an antidote to snakes and bites of other toxic insects (Ghani, 1998). Rhizome and leaf decoction are orally given in snake bite in the rural areas of Kanyakumari district, India (Jeeva et al., 2006).

The present investigation explored Naja naja venom neutralizing activity of Rauvolfia serpentina root extracts by in vitro, in vivo methods and antivenom compounds were identified using LCMS analysis.

\section{MATERIAL AND METHODS}

\section{Collection and authentication of plant material:}

Rauvolfia serpentina (L.) Benth. ex Kurz. (Ophioxylon serpentinum L.) belongs to the family Apocynaceae was collected from Anakkal region, Malampuzha, Palakkad district, Kerala after questionnaire with tribal people and from vaidyas in and around Palakkad district. It was authenticated by Dr. Althaf Ahamed Kabeer. Scientist 'D'. Botanical Survey of India Southern Regional Centre. Coimbatore (Herbarium voucher specimen number 1160).

\section{Preparation of extract}

$20 \mathrm{~g}$ of powdered sample of the herb was extracted by soaking in $180 \mathrm{~mL}$ of distilled water in a beaker, stirred for about $6 \mathrm{~min}$ and left over night. Thereafter, the solution was filtered using filter paper (What man No. 1) and the extracts were evaporated to dryness under reduced pressure in $40{ }^{\circ} \mathrm{C}$. The plant extracts were expressed in terms of dry weight.
Extraction yields $(\%)=($ weight of freeze dried extract *100/weight of original sample).

Extraction yields of Rauvolfia serpentina is $2.5 \%$

\section{Snake venom}

The freeze-dried snake venom powders of Naja naja were obtained from Irula's Snake Catchers Industrial Co-operative Society Limited Chennai and was stored at $4{ }^{\circ} \mathrm{C}$. Stock solution was prepared by dissolving $1 \mathrm{mg}$ of lyophilized venom in $1 \mathrm{~mL}$ of physiological saline $(1 \mathrm{mg} / \mathrm{mL})$. (Ethics committee approval number: JSSCP/ IAEC/PH.D/PH.COLOGY/02/2014-15)

\section{Acute oral toxicity}

Acute oral toxicity of all the selected plant extracts was performed as per OECD guidelines 423. A limit test of $2000 \mathrm{mg} / \mathrm{kg}$ body weight of the extracts was administered. Briefly, two thousand milligrams of the test substance per kilogram of body weight were administered to 3 healthy mice by oral gavages. The animals were observed for mortality, signs of gross toxicity, and behavioral changes at least once daily for 14 days. Body weights were recorded prior to administration and again on Days 7 and 14 (day of termination). Necropsies were performed on all animals at terminal sacrifice.

\section{In vitro assessment of venom toxicity and neutralization assays}

\section{Acetyl cholinesterase activity}

Acetyl cholinesterase inhibition assay was carried out according to the modified method of Ellman et al. (1961). $200 \mu \mathrm{g}$ of venom ( $1 \mathrm{mg} / \mathrm{mL})$ was pre-incubated $(1 \mathrm{~h})$ with different concentrations of plant extract and supernatant was added to the assay mixture which consists of $100 \mu \mathrm{L}$ of $75 \mathrm{mM}$ acetylcholine idodate in $1 \mathrm{~mL}$ of phosphate buffer. The activity was measured by taking the absorbance at $412 \mathrm{~nm}$. Venom without plant extracts was considered as control or $100 \%$ activity

$$
\text { Inhibition } \%=\text { control-test } / \text { control x100 }
$$

\section{Proteolytic activity}

Proteolytic activity was determined according to 
the method Satake, Murata and Suzuki (1963). Using 2\% casein as substrate in $0.02 \mathrm{M}$ Tris-HCl buffer ( $\mathrm{pH} 8.5$ ). Venom $200 \mu \mathrm{g}(1 \mathrm{mg} / \mathrm{mL})$ and different dilutions of plant extract were pre- incubated with $1 \mathrm{~mL}$ of substrate for $2 \mathrm{~h}$ at $37^{\circ} \mathrm{C}$. The undigested casein was precipitated by the addition of $1.5 \mathrm{~mL}$ of $0.44 \mathrm{M}$ trichloroacetic acid (TCA) and centrifuged. The digested casein in the supernatant was determined using Folin ciocalteu's reagent. Venom without plant extracts was considered as control or $100 \%$ activity.

Inhibition $\%=$ control-test/control x100

\section{ATPase activity}

ATPase activity was measured according to the modified method of Kini and Gowda (1982). Naja naja venom $200 \mu \mathrm{g}(1 \mathrm{mg} / \mathrm{mL})$ were pre-incubated with different concentrations of plant extract of Rauvolfia serpentina root for 30 minutes. To the reaction, $1 \mathrm{~mL}$ of assay mixture $(750 \mu \mathrm{L}$ of $0.1 \mathrm{M}$ Tris $\mathrm{pH} 7.5,100 \mu \mathrm{L}$ of $0.1 \mathrm{MgCl} 2,50 \mu \mathrm{L}$ of $0.1 \mathrm{M} \mathrm{ATP}$, and $100 \mu \mathrm{L}$ of BSA) was added with gentle shaking at $37^{\circ} \mathrm{C}$ and stopped at a certain time $(1 \mathrm{~h})$ by adding $1 \mathrm{~mL}$ of SDS solution. The inorganic phosphate formed was determined by phosphate determination method by taking $400 \mu \mathrm{L}$ of sample along $600 \mu \mathrm{L}$ of TCA and incubated separately for $10 \mathrm{~min}$ at $37^{\circ} \mathrm{C}$ followed by centrifugation at $1500 \mathrm{rpm}$ for $10 \mathrm{~min}$. About $500 \mu \mathrm{L}$ of supernatant was added together with $500 \mu \mathrm{L}$ of ferrous sulphate-ammonium molybdate reagent and the absorbance was measured at $820 \mathrm{~nm}$ within $2 \mathrm{~h}$ for every 10 minutes of intervals. Reaction mixture without plant sample was referred as control or $100 \%$ activity. Inhibition reaction was calculated in terms of percentage $(100 \%)$. Na,K-ATPase were mainly used.

$$
\text { Inhibition } \%=\text { control-test } / \text { control } \times 100
$$

\section{In vivo assessment of venom toxicity and anti- venom effect of plant extracts lethal toxicity}

The median lethal dose $\left(\mathrm{LD}_{50}\right)$ of Naja naja venom was determined according to the method of Randhawa (1944).Various doses of venom in $0.2 \mathrm{~mL}$ of physiological saline were injected into the tail vein of mice, using groups of 3-5 mice for each venom dose. The $\mathrm{LD}_{50}$ was calculated with confidence limit at $50 \%$ probability by the analysis of deaths occurring within $24 \mathrm{~h}$ of venom injection.

The anti-lethal potentials for plant extract were determined against $2 \mathrm{LD}_{50}$ of Naja naja venom. Various amount of plant extracts $(\mu \mathrm{L})$ were mixed with $2 \mathrm{LD}_{50}$ of venom sample and incubated at $37^{\circ} \mathrm{C}$ for 30 minutes and then injected intravenously into mice. 3-5 mice were used at each antivenom dose. Control mice received same amount of venom without antivenom (plant extracts). The median Effective Dose $\left(\mathrm{ED}_{50}\right)$ calculated from the number of deaths within $24 \mathrm{~h}$ of injection of the venom/antivenom mixture. $\mathrm{ED}_{50}$ was expressed as $\mu \mathrm{L}$ antivenom/mouse and calculated by probit analysis (Miller, Tainter, 1944).

\section{LC-MS analysis}

Phytochemical screening for compounds present in the aqueous extract from Rauvolfia serpentina root was carried out using LC Column: Reverse Phase C-18. The chromatographic separation was performed on a Phenomenex RP C-18 (25 cm x2.5 mm ) at Column temperature: $25^{\circ} \mathrm{C}$. A gradient Electronic Spray Ionization mode was performed at a flow rate of $2 \mathrm{~mL} / \mathrm{mins}$. The mobile phase: water: methanol (40:50). The volume of injection was $10 \mu \mathrm{L}$. Mass spectrometry data were obtained both positive and negative ionization modes. Class V P Integrated Soft Ware was used for the MS analysis and analyzed samples were compared with METWIN 2.0 library. These antivenom compounds were detected by PASS software. The computer program PASS (Prediction of Activity Spectra for Substances) was designed to predict many kinds of biological activity simultaneously based on the structural formulae of chemical compounds (Filimonov, Poroikov, Karaicheva, 1995; Poroikov, Filimonov, 1996).

\section{Statistical analysis}

Statistical evaluation was performed using XL stat 2008 and SPSS 10 Software $<0.005$ was considered statistically significant.

\section{RESULTS}

\section{Inhibition of Acetyl cholinesterase activity}

The aqueous extract of the plant was taken in different dilutions starting from $200 \mu \mathrm{g}$ to $300 \mu \mathrm{g}$ with triplicate experiments. Maximum of Acetyl cholinesterase inhibition (60.29\%) was occurred at $300 \mu \mathrm{g}$ concentration of venom and aqueous extract of plant respectively. The activity was calculated in terms of percentage of inhibition compared to venom pre-incubated with different amounts of plant extract and venom with substrate. The enzyme reaction was observed for every 10 minutes intervals at $412 \mathrm{~nm}$. Acetyl cholinesterase activity of the venom was considered as 100\%. (Figure 1) and (Table I). 
TABLE I - Acetylcholinesterase activity on Naja naja venom

\begin{tabular}{lcccc}
\hline Venom sample & $\begin{array}{c}\text { Concentration of } \\
\text { plant extract }(\boldsymbol{\mu g})\end{array}$ & $\begin{array}{c}\text { OD and } \\
\text { Inhibition \% }\end{array}$ & $\begin{array}{c}\text { Rauvolfia serpentina } \\
\text { root }\end{array}$ & Control \\
\hline Naja naja & 200 & OD & 0.53 & .68 \\
& \multirow{2}{*}{250} & Inhibition \% & 22.05 & \\
& \multirow{2}{*}{300} & OD & 0.37 & .68 \\
& Inhibition \% & 45.48 & .68 \\
\hline
\end{tabular}

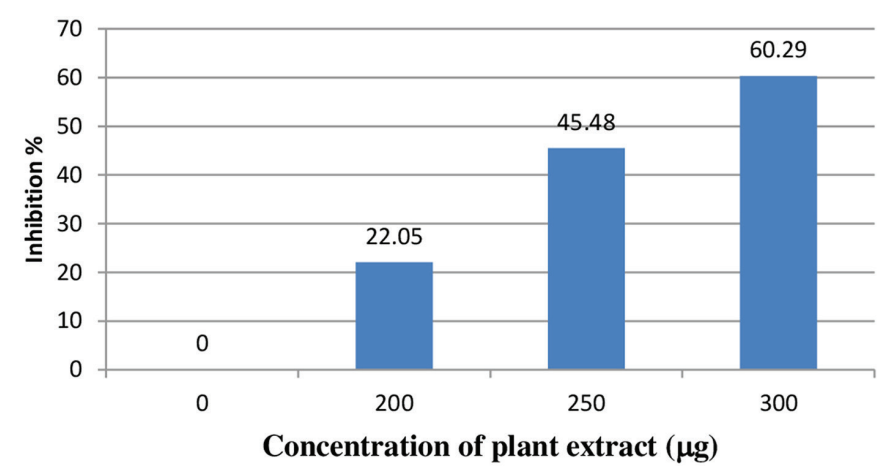

FIGURE 1 - Acetylcholinesterase inhibition assay.

\section{Inhibition of protease activity}

To assess the in vitro antagonism of protease, the venom degrades the substrate (casein) into peptide precipitation could be observed at $600 \mathrm{~nm}$. Maximum of protease inhibition $(50.40 \%)$ was occurred at 300 $\mu \mathrm{g}$ concentrations of venom and aqueous extract of plant respectively. From the results it was observed that increased amount of plant extract could increase the inhibition of protease of cobra activity (Figure 2 and Table II).

\section{Inhibition of ATPase activity}

ATPase inhibition was calibrated by liberation of inorganic phosphate with of positive control of venom

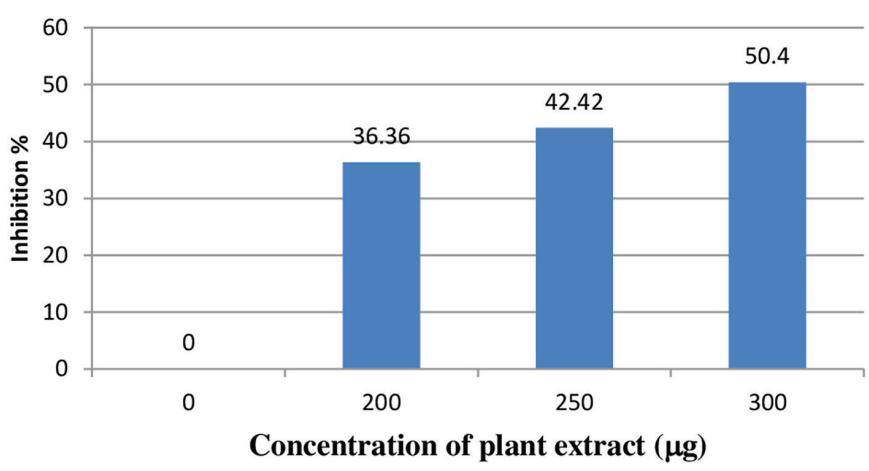

FIGURE 2 - Protease inhibition assay.

$(200 \mu \mathrm{g})$ and substrate as ATP $(10 \mu \mathrm{m})$. Different concentrations of venom and substrate were used for this reaction. The same concentration of venom $200 \mu \mathrm{g}$ with different amounts of active aqueous extract from the plant $(200 \mu \mathrm{g}$ to $300 \mu \mathrm{g}$ ) was pre- incubated for the reaction. Maximum inhibition up to $58.76 \%$ has been noted at highest amount of plant concentration (Figure 3 and Table III).

\section{In vivo methods}

In vivo assessment of venom toxicity $\left(\mathrm{LD}_{50}\right)$ of Naja naja venom was assessed by $\mathrm{LD}_{50}$ range finding test and the median lethal dose $\left(\mathrm{LD}_{50}\right)$ assay using mice (18$20 \mathrm{~g}) . \mathrm{LD}_{50}$ of Naja naja venom was calculated by Miller and Tainter method and was found to be $0.301 \mu \mathrm{g} / \mathrm{g}$.

TABLE II - Protease activity on Naja naja venom

\begin{tabular}{lcccc}
\hline Venom sample & $\begin{array}{c}\text { Concentration of } \\
\text { plant extract }(\boldsymbol{\mu g})\end{array}$ & $\begin{array}{c}\text { OD and } \\
\text { Inhibition \% }\end{array}$ & $\begin{array}{c}\text { Rauvolfia serpentina } \\
\text { root }\end{array}$ & Control \\
\hline Naja naja & 200 & OD & 0.42 & .65 \\
& \multirow{2}{*}{250} & Inhibition \% & 36.36 & .65 \\
& OD & 0.38 & .65 \\
\hline
\end{tabular}


TABLE III - Atpase activity on Naja naja venom

\begin{tabular}{lcccc}
\hline Venom sample & $\begin{array}{c}\text { Concentration of } \\
\text { plant extract(}(\boldsymbol{\mu g})\end{array}$ & $\begin{array}{c}\text { OD and } \\
\text { Inhibition \% }\end{array}$ & $\begin{array}{c}\text { Rauvolfia serpentina } \\
\text { root }\end{array}$ & control \\
\hline Naja naja & 200 & OD & 0.57 & .97 \\
& \multirow{2}{*}{250} & Inhibition \% & 41.23 & .97 \\
& OD & 0.52 & .97 \\
& \multirow{2}{*}{300} & Inhibition \% & 46.39 & .97 \\
\hline
\end{tabular}

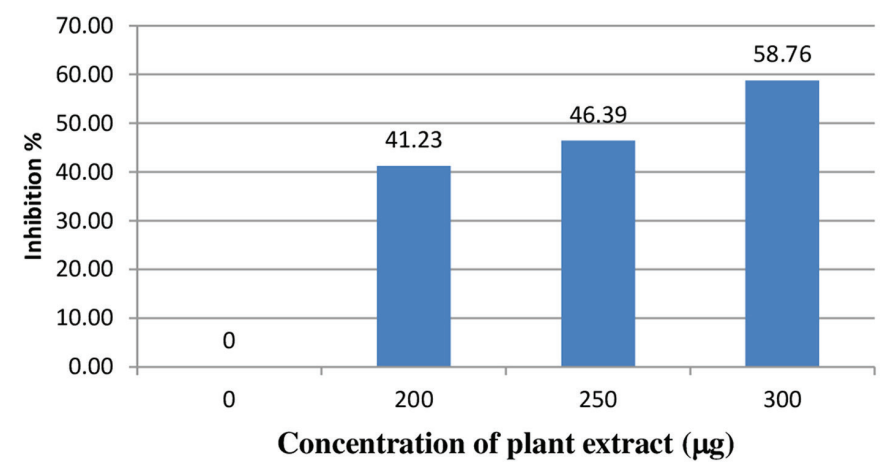

FIGURE 3 - ATPase inhibition assay.

(Table IV and Figure 4).Venom neutralizing potency tested $\left(\mathrm{ED}_{50}\right)$ using Rauvolfia serpentina root extract was carried out by pre incubating constant amount of venom $\left(3 \mathrm{LD}_{50}\right)$ with various dilutions of Rauvolfia serpentina root extract prior to injection. Calculation of $\mathrm{ED}_{50}$ of Rauvolfia serpentina root of $3 \mathrm{LD}_{50}$ of venom was found to be $12.88 \mu \mathrm{g}$ against Naja naja venom (Table V and Figure 5). All animals survived and appeared active and healthy throughout acute oral toxicity study. There were no signs of gross toxicity, antagonistic pharmacological effects or uncommon behavior. Based on the above findings, the $\mathrm{LD}_{50}$ of Rauvolfia serpentina root extract was $>2000 \mathrm{mg} / \mathrm{kg}$.

\section{LCMS analysis}

Various compounds were identified by LCMS analysis which includes D-glucuronic acid, triacontanol, alppha-ionine, hydroquinone, reserpinine, reserpine, ascorbic acid, gallic acid, hydrangenol and oleic acid and their activities were determined using PASS software. Among the compounds, D-glucuronic acid, triacontanol, reserpine, gallic acid and oleic acid possess antivenom activity due to inhibition of various snake venom enzymes activities like phospholipase $\mathrm{A}_{2}$ inhibition, ATPase inhibition, nucleotidase inhibition, 5'-nucleotidase inhibition, L-aminoacid oxidase inhibition, phosphodiesterase inhibition activity and have antidote activity (Table VI and Figure 6).

TABLE IV - Calculation of $\mathrm{LD}_{50}$ of Naja naja venom in mice receiving various doses of Naja naja venom by Miller and Tainter method $(\mathrm{n}=5)$

\begin{tabular}{lcccccc}
\hline Dose $(\boldsymbol{\mu g} / \mathbf{g})$ & $\begin{array}{c}\text { Adjusted } \\
(\text { Dose } \times \mathbf{1 0 0})\end{array}$ & Log dose & Death/Total & Dead \% & $\begin{array}{r}\text { Corrected } \\
\text { formula \% }\end{array}$ & Probit values \\
\hline 0.025 & 2.5 & 0.4 & $0 / 5$ & 0 & 5 & 3.36 \\
0.05 & 5 & 0.7 & $1 / 5$ & 0 & 20 & 4.16 \\
0.1 & 10 & 1 & $1 / 5$ & 20 & 20 & 4.16 \\
0.25 & 25 & 1.4 & $2 / 5$ & 40 & 40 & 4.75 \\
0.5 & 50 & 1.7 & $3 / 5$ & 60 & 60 & 5.25 \\
1.0 & 100 & 2.0 & $4 / 5$ & 80 & 80 & 5.84 \\
2.5 & 250 & 2.4 & $4 / 5$ & 80 & 80 & 5.84 \\
5.0 & 500 & 2.7 & $5 / 5$ & 100 & 95 & 6.64 \\
\hline
\end{tabular}

Corrected formula: For the $0 \%$ dead: $100(0.25 / \mathrm{n})=100(0.25 / 5)=5$. For the $100 \%$ dead: $100[(\mathrm{n}-0.25) / \mathrm{n}]=100[(5-0.25) / 5]=95$, $\mathrm{n}$ is the number of animals in the group 
TABLE V - Calculation of $\mathrm{ED}_{50}$ of Rauvolfia serpentina against Naja naja venom in mice by Miller and Tainter method ( $\mathrm{n}=5$ )

\begin{tabular}{lcccccc}
\hline Dose $(\boldsymbol{\mu g} / \mathbf{g})$ & $\begin{array}{c}\text { Adjusted } \\
\text { (Dose } \times \mathbf{1 0 0})\end{array}$ & Log dose & Survival/Total & Dead \% & $\begin{array}{c}\text { Corrected } \\
\text { formula \% }\end{array}$ & Probit values \\
\hline 1 & 100 & 2 & $0 / 5$ & 0 & 5 & 3.36 \\
2.5 & 250 & 2.4 & $0 / 5$ & 0 & 5 & 3.36 \\
5 & 500 & 2.7 & $1 / 5$ & 20 & 20 & 4.16 \\
10 & 1000 & 3 & $1 / 5$ & 40 & 40 & 5.16 \\
20 & 2000 & 3.3 & $3 / 5$ & 60 & 60 & 5.25 \\
40 & 4000 & 3.6 & $4 / 5$ & 80 & 95 & 5.84 \\
$\mathbf{8 0}$ & $\mathbf{8 0 0 0}$ & $\mathbf{3 . 9}$ & $\mathbf{5 / 5}$ & $\mathbf{1 0 0}$ & $\mathbf{9 5}$ & $\mathbf{6 . 6 4}$ \\
\hline
\end{tabular}

Corrected formula: For the $0 \%$ dead: $100(0.25 / \mathrm{n})=100(0.25 / 5)=5$. For the $100 \%$ dead: $100[(\mathrm{n}-0.25) / \mathrm{n}]=100[(5-0.25) / 5]=95$, $\mathrm{n}$ is the number of animals in the group.

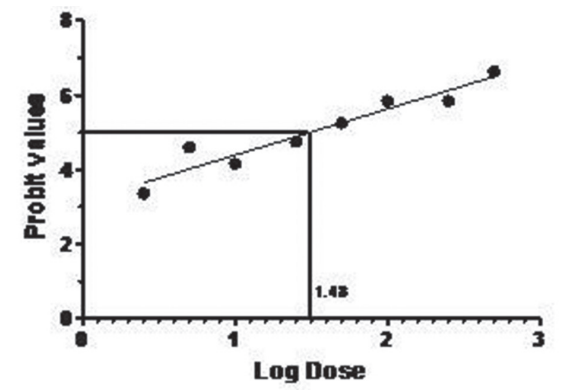

$$
\begin{aligned}
& \mathrm{LD}_{50} \text { of Naja naja } \\
& =\operatorname{antilog}(\log \text { dose }) / 100 \\
& =\operatorname{antilog} 1.48 / 100 \\
& =30.19 / 100 \\
& =0.301 \mu \mathrm{g} / \mathrm{g}
\end{aligned}
$$

FIGURE 4 - Calculation of lethal dose of Naja naja venom.

\section{DISCUSSION}

During the last few years there has been an increasing interest in the study of medicinal plants and their traditional use of different parts of India. In the recent years number of reports on the use of plants in traditional healing by either tribal people or indigenous communities of India is increasing (Namsa et al., 2009; Upadhyay, Dhaker, Kumar, 2010). The herbal medicines are mostly administered in the form of juice, decoction, paste or powder, prepared in a crude method from different plant parts such as root, bark, leaves, flowers, fruits, seeds and whole plant (Sarada et al., 2008). The aqueous extracts were selected for the study because the 'vishavaidayas' used only the aqueous extracts to treat the ill effects of snake bite. Earlier research on

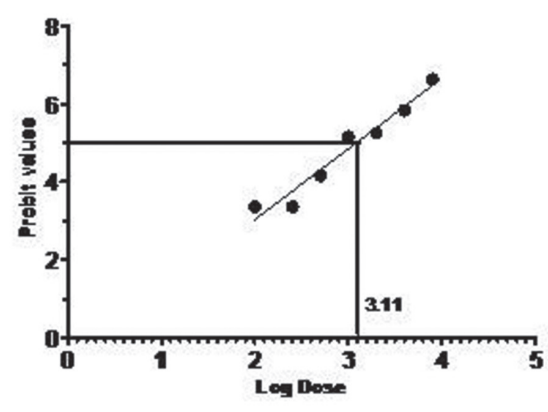

ED 50 of Rauvolfia serpentina against Naja naja venom
$=\operatorname{antilog}(\log$ dose $) / 100$
$=\operatorname{antilog} 3.11 / 100$
$=1288 / 100$
$=12.88 \mathrm{mg}$

FIGURE 5 - ED50 of Rauvolfia serpentina against Naja naja venon.

plants as antivenom also supports the use of aqueous extract (Houghton, Osibogun, 1993). Singh (2008) has stated the ethno remedial use of Rauvolfia serpentina plant against snake bite. Root decoction is being used as an antidote to snake venom in some tribal rich district of Orissa, India (Behera, Sahoo, Mohapatra, 2007). About 10 $\mathrm{mL}$ of root paste is taken orally for management of snake bite by the forest inhabitants of the Daitari range of hills of Orissa, India (Mohapatra, Prusty, Sahoo, 2008). Pattanaik, Reddy and Reddy (2009) have informed the use of this plant (Known as Patalgaruda locally) by the local people of Eastern Ghats, India against snakebite. In our present investigation antivenom potential for Rauvolfia serpentina aqueous root extract against Naja naja venom was studied by in vivo and in vitro methods 
TABLE VI - Activities of the compounds identified from the extract of Rauvolfia serpentina root by LC-MS analysis (PASS)

\begin{tabular}{|c|c|c|c|c|}
\hline SL NO & Compound name & Molecular mass & $\begin{array}{c}\text { Molecular } \\
\text { formula }\end{array}$ & Activities on Snake Venom \\
\hline 1 & D-Glucuronic acid & 194.14 & $\mathrm{C}_{6} \mathrm{H}_{10} \mathrm{O}_{7}$ & $\begin{array}{l}\text { Antidote, ATPase inhibitor, L-amino-acid oxidase } \\
\text { inhibitor, Acute neurologic disorders treatment } \\
\text { Phospholipase A1,A2 inhibitor, 5'-Nucleotidase } \\
\text { inhibitor }\end{array}$ \\
\hline 2 & Triacontanol & 438.81 & $\mathrm{C}_{30} \mathrm{H}_{62} \mathrm{O}$ & $\begin{array}{l}\text { Antidote, Phospholipase activity, } 5 \text { 'nucleotidase } \\
\text { inhibitor }\end{array}$ \\
\hline 3 & Alppha-ionine & 192.32 & $\mathrm{C}_{13} \mathrm{H}_{20} \mathrm{O}$ & ATPase inhibitor. \\
\hline 4 & Hydroquinone & 110.11 & $\mathrm{C}_{6} \mathrm{H}_{6} \mathrm{O}_{2}$ & $\begin{array}{l}\text { L-aminoacid oxidase inhibitor, 5'nucleotidase } \\
\text { inhibitor, ATPase inhibitor }\end{array}$ \\
\hline 5 & Reserpinine & 634.74 & $\mathrm{C}_{22} \mathrm{H}_{26} \mathrm{~N}_{2} \mathrm{O}_{4}$ & Phosphodiesterase inhibitor \\
\hline 6 & Reserpine & 608.69 & $\mathrm{C}_{33} \mathrm{H}_{40} \mathrm{~N}_{2} \mathrm{O}_{9}$ & Antidote, Phosphodiesterase inhibitor \\
\hline 7 & Ascorbic acid & 176.12 & $\mathrm{C}_{6} \mathrm{H}_{8} \mathrm{O}_{6}$ & ATPaseinhibitor, 5'nucleotidase inhibitor \\
\hline 8 & Gallic acid & 170.13 & $\mathrm{C}_{7} \mathrm{H}_{6} \mathrm{O}_{5}$ & $\begin{array}{l}\text { Antidote, ATPase inhibitor, venom exonuclease } \\
\text { inhibitor, Acute neurological disorder treatment, } \\
5 \text { '-Nucleotidase inhibitor }\end{array}$ \\
\hline 9 & Hydrangenol & 256.26 & $\mathrm{C}_{15} \mathrm{H}_{12} \mathrm{O}_{4}$ & ATPase inhibitor activity, Phospholipase inhibitor \\
\hline 10 & Oleic acid & 282.47 & $\mathrm{C}_{18} \mathrm{H}_{34} \mathrm{O}_{2}$ & L-aminoacid oxidase inhibitor, ATPase inhibitor \\
\hline
\end{tabular}

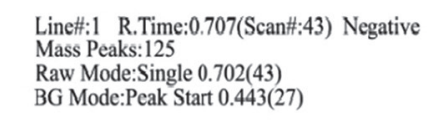

MS Spectrum

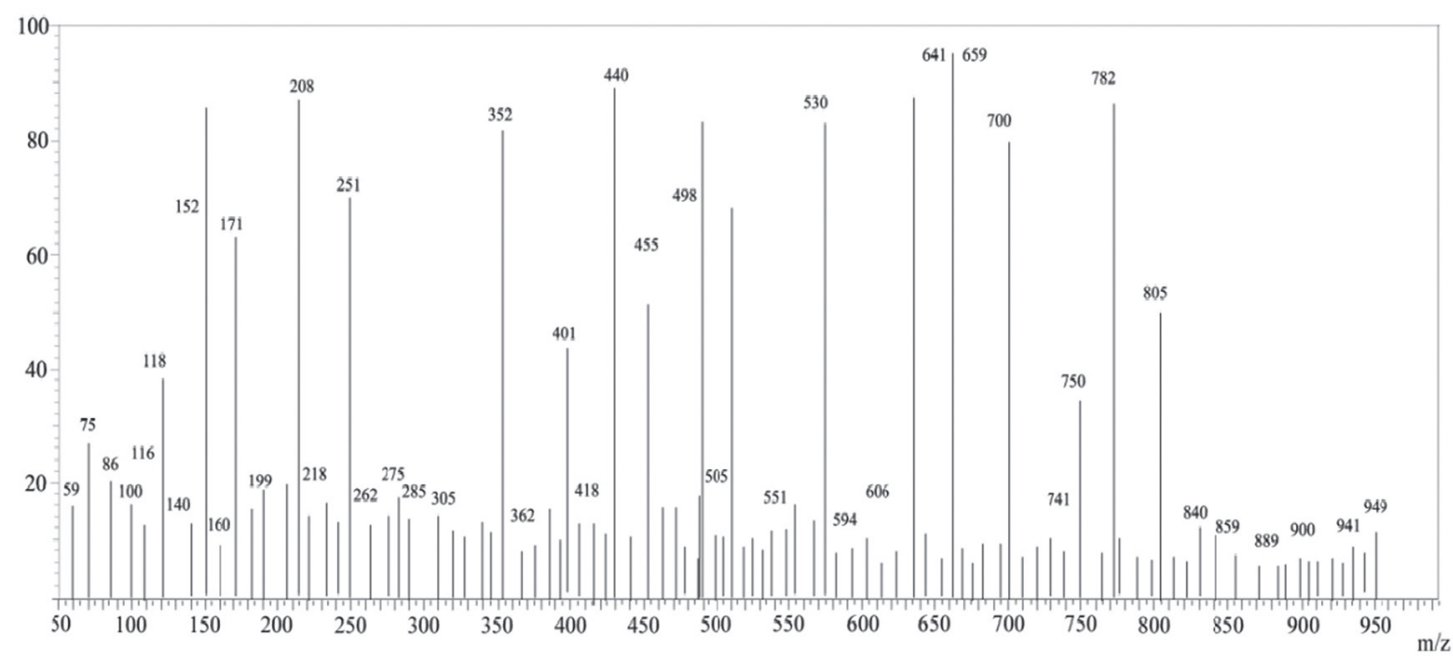

FIGURE 6 - LCMS analysis Rauvolfia serpentina root.

\section{In vitro neutralization assays}

Maximum of Acetyl cholinesterase inhibition (60.29\%), protease inhibition $(50.40 \%)$, and ATPase inhibition (58.76\%) was occurred for $300 \mu \mathrm{g}$ concentration of aqueous plant extract. The inhibition of Naja naja venom enzymes by increased amounts of aqueous extract from Rauvolfia serpentina was very effective, when the extract was previously mixed with venom. There was a substantial deactivation of Acetyl cholineesterase, Protease, ATPase activities. The studies of Kadiyala (2011) have also reported the inhibition of Naja naja venom enzymes by increased amounts of methanol extracts from Andrographis paniculata. 


\section{In vivo neutralization assays}

The plant extract effectively neutralized the Naja naja venom induced lethal activity. About $0.14 \mathrm{mg}$ of Rauvolfia serpentina plant extract was able to completely neutralize the lethal activity of $2 \mathrm{LD}_{50}$ of Naja naja venom. The alkaloid reserpine inhibits the action of phospholipase- A2 enzyme from Naja naja venom. In our study In vivo assessment of venom toxicity $\left(\mathrm{LD}_{50}\right)$ of Naja naja venom was assessed by $\mathrm{LD}_{50}$ range finding test and the median lethal dose $\left(\mathrm{LD}_{50}\right)$ assayed using mice $(18-20 \mathrm{~g}) . \mathrm{LD}_{50}$ of Naja naja venom was calculated by Miller and Tainter method and was found to be $0.301 \mu \mathrm{g} / \mathrm{g}$ .Venom neutralizing potency tested $\left(\mathrm{ED}_{50}\right)$ using Rauvolfia serpentina root extract was done by Miller and Tainter method and was found to be $12.88 \mathrm{mg}$ against Naja naja venom. In previous report on Rajasree, Singh and Sankar (2013) the ethanol extracts from Rauvolfia serpentina plant were tested for antivenom activity against Naja naja venom. The plant extract effectively neutralized the Naja naja venom induced lethal activity. About $0.14 \mathrm{mg}$ of Rauvolfia serpentina plant extract was able to completely neutralize the lethal activity of $2 \mathrm{LD}_{50}$ of Naja naja venom. In another study of James et al. (2013) of in vivo and in vitro neutralizing potential of Rauvolfia serpentina plant extract against Daboia russelli venom, Rauvolfia serpentina plant extract was effectively neutralized the venom lethality and effective dose (ED) was found to be $10.99 \mathrm{mg} / 3 \mathrm{LD}$ of venom

The tests of determining venom lethality $\left(\mathrm{LD}_{50}\right)$ and antivenom neutralizing capacity $\left(\mathrm{ED}_{50}\right)$ are currently the only validated means of assessing venom toxicity and antivenom neutralizing potency by both manufacturers and regulatory authorities worldwide. There were no signs of gross toxicity, antagonistic pharmacological effects or uncommon behavior.

\section{LCMS analysis of aqueous extract of Rauvolfia serpentina root}

In the present study the phytochemical profile of aqueous extract from Rauvolfia serpentina root were characterized. Various antivenom compounds were detected from LCMS analysis of aqueous root extract which includes D-glucuronic acid, triacontanol, reserpine, gallic acid and oleic acid due to inhibition of various snake venom enzymes activities like phospholipase $\mathrm{A}_{2}$ inhibition, ATPase inhibition, nucleotidase inhibition, 5 'nucleotidase inhibition, L-aminoacid oxidase inhibition, phosphodiesterase inhibition activity and have antidote activity. Active phytochemical compounds like D-glucuronic acid, gallic acid, oleic acid isolated from different plant sources, have already been proven for their anti-venom potential (Butt et al., 2015). The alkaloid reserpine inhibits the action of phospholipase- A2 enzyme from Naja naja venom. Many plant extracts have been reported to possess a detoxifying effect on snake venoms (Haruna, Choudhury, 1995). The mechanism of action of the plant extracts/plant compounds are still not clear and they may be attributed to the blocking of receptorsstructure prone to chemical attack, and may block the active site of the snake venom. Hence, the presence of these anti snake venom compounds in the aqueous extract from Rauvolfia serpentina root could have contributed to its efficient antivenom activity.

\section{ACKNOWLEDGEMENT}

The authors are thankful to Principal Dr. Anirudhan, for providing the necessary facilities in the College and sincerely thanks to Dr. J. Rathinamala, Head, Department of Microbiology, Nehru Arts and Science College, Coimbatore, for her encouragement and support throughout the study.

\section{REFERENCE}

Bawaskar HS. Snake bite poisoning: A neglected life-threatening occupational hazard. Indian J Crit Care Med. 2014.18(1):123-4.

Behera KK, Sahoo S, Mohapatra PC. Medicinal Plant Resources for Bioprospecting and Drug Development in Tribal Rich District of Orissa, India. Ethnobot Leaflets. 2007;11:106-112.

Butt MA, Ahmad M, Fathima A, Sultana S, Zafar M, Yaseen $\mathrm{G}$, et al. Ethno medicinal uses of plants for the treatment of snake and scorpion bite in Northern Pakistan. J Ethnopharmacol. 2015;168:164-181.

Deshmukh SR, Dhanashree SA, Patil BA. Extraction and evaluation of Indole alkaloids from Rauvolfia serpentina for their antimicrobial and antiproliferative activities. Int J Pharm Pharm Sci. 2012;4:329-334.

Ellman GL, Courtney KD, Andres V, Featherstone RM. A new and rapid colorimetric determination of acetyl cholinesterase activity. Biochem Pharmacol. 1961;7(2):88-95.

Filimonov DA, Poroikov VV, Karaicheva EI. Computer-aided prediction of biological activity spectra of chemical substances on the basis of their structural formulae: computerized system pass. Exper Clin Pharmacol. (Rus). 1995;58:56-62. 
Ghani A. Medicinal plants of Bangladesh chemical constituents and uses. Bangladesh: Asiat Soc Bangladesh; 1998; 2:36.

Gutierrez JM, Williams D, Fan HW, Warrell DA. Snakebite envenoming from a global perspective: Towards an integrated approach. Toxicon. 2010;56(7):1223-1235.

Harrison RA, Hargreaves A, Wagstaff SC, Faragher B, Lalloo DG. Snake envenomation: a disease of poverty. PLoS Negl Trop Dis. 2009;3(12):e569.

Haruna AK, Choudhury MK. In vivo antisnake venom activity of the furanoid diterpene from Aristolochia albida Duch. Indian J Pharm Sci. 1995;27:222-224.

Houghton PJ, Osibogun IM. Flowering plant used against Snakiebite. J Ethnopharmacol. 1993;39(1):1-29.

James T, Dinesh MD, Uma MS, VadivelanAS, Meenathisundaram $\mathrm{S}$, Shanmugam V. In vivo and In vitro neutralizing potential of Rauvolfia serpentine plant extract against Daboia russelli venom. Adv Biol Res. 2013;7(6):276-281.

Jeeva S, Kiruba S, Mishra BP, Venugopal N, Dhas SSM, Regini $\mathrm{GS}$, et al. Weeds of kanyakumari district and their value in rural life. Indian J Tradit Know. 2006;5(4):501-509.

Kadiyala $\mathrm{G}$. The neutralization effect of methanol extract of Andrographis paniculata on Indian cobra Naja naja snake venom. J Pharm Res. 2011;4(4):1010-1012.

Kang TS, Georgieva D, Genov N, Murakami TM, Sinha M, Kumar RP. Enzymatic toxins from snake venom: structural characterization and mechanism of catalysis. FEBS. 2011;278(23):4544-76.

Khan AV, Ahmed QU, Khan MW, Khan AA. Herbal cure for poisons and poisonous bites from Western Uttar Pradesh, India. APJTD. 2014;4(1):116-120

Kini RM, Gowda TV. Studies on snake venom enzymes: Part 1 Purification of ATPase, a toxic component on Naja naja venom and its inhibition by potassium gymnemate. Indian J Biochem Biophys. 1982;19(2):152-154

Mallick SR, Jenna RC, Samal KC. Rapid in vitro multiplication of an endangered medicinal plant sarpagandha( Rauvolfia serpentina). AJPS. 2012;3(2):437-442.
Miller LC, Tainter ML. Estimation of LD50 and its error by means of log-probit graph paper. Proc Soc Exp Biol Med. 1944;57:261.

Mohapatra B, Warrell DA, Suraweera W, Bhatia P, Dhingra N, Jotkar R. Snake bite mortality in India: A nationally representative mortality survey. PLOS Negl Trop Dis. 2011;5(4):e1018.

Mohapatra SP, Prusty GB, Sahoo HP. Ethnomedicinal observations among forest dwellers of the Daitari Range of Hills of Orissa, India. Ethnobo Leaflets. 2008;12:1116-1123.

Mukherjee AK. Green medicine as a harmonizing tool to antivenum therapy. Indian J Med Res. 2012;136(1):10-12.

Namsa ND, Tag H, Mandal M, Kalita P, Das AK. An ethnobotanical study of traditional anti-inflammatory plants used by the Lohit community of Arunachal Pradesh, India. J Ethnopharmacol. 2009;125(2):234-245.

Pattanaik C, Reddy S, Reddy KN. Ethno-medicinal survey of threatened plants in Eastern Ghats, India. Our Nature. 2009;7(1):122-128.

Poroikov VV, Filimonov DA. QSAR and molecular modelling concept, computational tools and biological applications. Barcelona: Prous Science Publishers; 1996, p.49-50.

Rajasree PH, Singh R, Sankar C. Anti venom activity of ethanolic extract - of Rauvolfia serpentina against Naja naja(Cobra)venom. IJDDHR. 2013;3:521-524.

Randhawa MA. Calculation of $\mathrm{LD}_{50}$ values from the method of Miller and Tainter. J Ayub Med Coll Abbottabad. 1944;21(3):184-5.

Rathore SK, Bhatt S, Dhyani S, Jain A. Preliminary phytochemical screening of medicinal plant Ziziphus Mauritiana Lam. Fruits. IJCPRF. 2012;4(3)160-162.

Sarada P Mohapatra, Gagan B Prusty, Hara P Sahoo. Ethnomedicinal observations among forest dwellers of the Daitari Range of Hills of Orissa, India. Ethnobotanical Leaflets. 2008;12:1116-23.

Sarkhel S, Chakravarthy AK, Das R, Gomes A. Snake venom neutralizing factor from root extract of Emblica officinalis Linn. Orient Pharm Exp Med. 2011;11(1):25-33. 
Satake M, Murata Y, Suzuki T. Studies on Snake venom. Biochem. 1963;53:438-447.

Singh H. Importance of local names of some useful plants in ethnobotanical study. Indian J Tradit Know. 2008;7(2):365-370.

Upadhyay B, Parveen Dhaker AK, Kumar A. Ethnomedicinal and ethnopharmaco-statistical studies of Eastern Rajasthan, India. J Ethnopharmacol. 2010;129(1):64-86.
Vijaya P, Ranjani R, Rao MR, Sudarsanan G. Impact of antidote medicinal plant-corallocarpus epigeus extract on lipid peroxidation induced by Naja naja-snake venom in albino rat. Int J Med Pharm Sci. 2013;3(5):23-30.

Received for publication on $20^{\text {th }}$ January 2018 Accepted for publication on $13^{\text {th }}$ November 2018 